\title{
$\mathrm{PV}$ 시스템이 설치된 대학건물의 전력 생산에 따른 신재생에너지 공급비율 분석
}

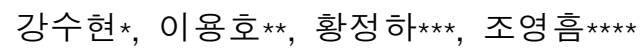 \\ *금오공과대학교 대학원 건축공학과(tngus4u@kumoh.ac.kr) \\ **경북대학교 건축도시환경공학부(sms5379@naver.com) \\ ***경북대학교 건축도시환경공학부(peter@knu.ac.kr) \\ *****금오공과대학교 건축학부(yhcho@kumoh.ac.kr)
}

\section{The analysis of the renewable energy supply ratio for the school building applied PV system}

Kang, Su-Hyun* Lee, yong-Ho** Hwang, Jung-Ha** Cho, Young-Hum****

*Dept. of Architectural Eng, Kumoh National Institute of Technology(tngus4u@kumoh.ac.kr) $* *$ School of Architecture \& Urban Environmental Eng, Kyungpook National University(sms5379@naver.com)

***School of Architecture \& Urban Environmental Eng, Kyungpook National University(peter@knu.ac.kr) ****School of Architecture, Kumoh National Institute of Technology(yhcho@kumoh.ac.kr)

\begin{abstract}
Recently the renewable energy has been used widely and the importance of renewable sources is bigger than before. And the government enforced a law to the public buildings to install the renewable energy facilities. The capacity of facilities was 5\% of total construction cost until April 13, 2011. Since then, the government changed the law from $5 \%$ of total construction cost to $10 \%$ of predicted energy usage for the resonable use of the renewable energy facilities. In this study, the comparative analysis is conducted according to the law to the building installed PV system through the Energy Plus simulation. And the method for improving renewable energy supply ratio was analyzed using existing PV array. Adjusting the PV array angle is the best way to generate more electric power without additional fee. When applying the month optimum angle, $3,600 \mathrm{kWh}$ of electric power are more generated compared to the existing angle.
\end{abstract}

Keywords : 신재생 에너지(Renewable energy), PV 시스템(PV system), 공공건축물(Public building), Energy Plus simulation

투고일자 : 2012년 1월 11일, 심사일자 : 2012년 1월 13일, 게재확정일자 : 2012년 4월 24일

교신저자 : 조영흠(yhcho@kumoh.ac.kr) 


\section{기 호 설 명}

$\begin{array}{lll}\mathrm{Pm} & : & \text { 정격용량 }(\mathrm{W}) \\ \mathrm{IPm} & : & \text { 정격전류 }(\mathrm{A}) \\ \mathrm{VPm} & : & \text { 정격전압 }(\mathrm{V}) \\ \mathrm{Isc} & : & \text { 단락전류 }(\mathrm{A}) \\ \mathrm{Voc} & : & \text { 개방전압 }(\mathrm{V})\end{array}$

\section{1. 서 론}

\section{1 연구의 목적}

현재 전 세계는 고갈되는 화석연료와 온실 가스 감축을 위하여 신재생에너지에 대한 관 심이 높아지고 있으며, 미국, 유럽, 일본 등의 선진국에서는 대체에너지의 개발과 보급이 범정부 차원에서 이루어지고 있다. 우리나라 는 에너지의 해외 의존도가 $97 \%$ 에 달하는 자 원 빈국으로서, 에너지 수급 불안정에 따른 에너지 안보 확보를 위해 신재생에너지 개발 및 보급에 박차를 가하고 있다. 그러한 정책 중 하나로서 공공기관이 신축하는 연면적 $3,000 \mathrm{~m} 2$ 이상의 건축물에 대하여 총 건축공 사비의 $5 \%$ 이상 신재생에너지 설치에 투자해 야 하는 신재생에너지 설치 의무화 사업을 2004년부터 시행해오고 있다. 그 결과 공공기 관을 중심으로 건물에 신재생에너지 설비를 도입하는 비율이 증가하였으며, 이후 2009년 3 월 증-개축하는 건물에까지 확대적용 되었 다. 그러나 이후 신재생에너지 설비의 적정 사용 및 효율성의 문제로 인하여 예상건물에 너지 사용량의 $10 \%$ 를 신재생에너지로 공급 토록 의무화하였으며 향후 관련 법규를 강화 해 나갈 예정에 있다.

따라서 본 연구에서는 법 개정 이전, 즉 총 건축공사비의 $5 \%$ 이상이 신재생에너지 설치 에 투자된 공공건물에 대하여 신재생에너지 공급비율을 분석하고, 기존의 신재생에너지 설비를 이용하여 추가비용 없이 효율을 향상 시키는 방안에 대하여 검토해 보고자 한다.

\section{2 연구 방법}

본 연구에서는 경북 구미에 위치한 $\mathrm{K}$ 대학 교 내의 태양광 발전설비가 설치된 업무시설 에 대하여, 태양광 발전설비의 발전량 및 신 재생에너지 공급비율에 대하여 분석하였다. 또한, 기존의 태양광 발전설비를 이용하여 추 가적인 비용 없이 효율을 향상시킬 수 있는 방안에 대하여 살펴보았다. 에너지 분석 도구 는 Energy Plus를 사용하였다.

\section{2. 기존 연구 고찰}

$\mathrm{PV}$ 시스템의 발전량에 가장 크게 영향을 미치는 요소는 태양광 어레이 표면에 입사하 는 일일 일사량이라 할 수 있으며, 이에 따라 태양광 어레이의 설치 각도 및 적정 향은 매 우 중요한 요소이다. 또한 추가적인 비용이 필요하지 않고 발전량을 향상시킬 수 있으므 로 설계시 적정 각도와 향의 설정은 반드시 고려되어야 한다. 이러한 관점을 바탕으로 기 존의 연구문헌을 분석하였다.

유권종 외 4 인의 '전문가 시스템을 이용한 태 양광 어레이의 최적설치 각도에 관한 연구(2007)' 에서는 이론식을 바탕으로 전문가시스템을 구축 하고 이를 통해 전국의 최적 경사각을 산출하였 다. 그 결과 전국 평균 태양광 어레이 설치 경사 각은 24 36 분포를 나타내었다. 제주도를 제외 한 전국의 최적 태양광 어레이 설치 경사각은 30 $\sim 36^{\circ}$ 이며, 이러한 경사각을 적용하였을 경우 최 대의 태양 일사를 받아들이는 것으로 나타났다.

송종화 외 5 인의 '건물일체형 투광성 $\mathrm{PV}$ 모듈의 설치 각도별 발전특성에 관한 연구 (2008)'에서 박막 태양전지를 이용한 PV 복 층창 시스템의 실제 건물 적용모델을 대상으 로 경사각별 발전성능을 측정하고 시뮬레이션 (TRNSYS) 결과와 비교 분석하였다. Mock-Up 모델의 경사각별 단위 출력량 분석 결과 $0^{\circ}$, $30^{\circ}, 90^{\circ}$ 의 경사각 중 $30^{\circ}$ 에서 발전량이 가장 높았으며, 시뮬레이션 결과 또한 Slope_30 $30^{\circ}$ 에 설치된 $\mathrm{PV}$ 모듈의 발전량이 가장 우수함을 
나타내었다. 방위각별 발전량 은 Slope_30을 기준으로 정남향에 설치된 $\mathrm{PV}$ 모듈이 가장 우수한 발전량을 나타내었다.

오명석 외 2 인의 '아파트에 적용된 태양광 발전 시스템의 성능평가 및 개선방안에 관한 연구(2008)'에서는 태양광발전 시스템이 설치 된 아파트를 대상으로 운전현황 및 실태를 파 악하고, 시스템의 성능평가 및 비교를 통하여 개선방안을 제시하였다. 또한, 태양광 발전 시스템에 영향을 주는 요인으로서 방위 및 설 치각도, 일사량 및 일조시간, 전지의 전력변 환효율, PV 시스템의 온도상승과 변환효율, 음영, 인동거리, 식생 등 7 가지 요소를 제시하 고, 이를 바탕으로 아파트에 적용된 태양광 설비 시스템 발전량을 분석하였다.

기존연구문헌을 분석한 결과 태양광 발전 시스템의 최적각도 및 태양광 발전에 영향을 주는 요인에 관하여 연구가 많이 이루어지고 있음을 알 수 있다. 본 연구는 이러한 연구를 바탕으로 실제 태양광 시스템이 설치된 건물 에 대하여 최적각도를 찾고, 전력생산에 따른 신재생에너지 공급비율을 분석하였다.

\section{3. $\mathrm{PV}$ 시스템의 설치현황}

\section{1 대상건물 개요}

대상건물은 경북 구미시에 위치한 $\mathrm{K}$ 대학 교의 업무용 건물을 선정하였다. 본 건물은 2010년 12월에 완공하였으며, 총 건축공사비 의 $5 \%$ 가 PV 발전 시스템에 투자되었다. PV 시스템은 2011년 2월부터 발전을 시작하였 다. 그림 1 은 대상건물의 전경이며, 표 1 은 대 상건물의 개요를 나타낸다.

표 1. 대상건물 개요

\begin{tabular}{c|c}
\hline 구분 & 내용 \\
\hline 위치 & 경북 구미시 \\
\hline 사용용도 & 업무시설 \\
\hline 규모 & 지하 1 층, 지상 7 층 \\
\hline 건축면적 & $2,611 \mathrm{~m}^{2}$ \\
\hline 연면적 & $6,580 \mathrm{~m}^{2}$ \\
\hline
\end{tabular}

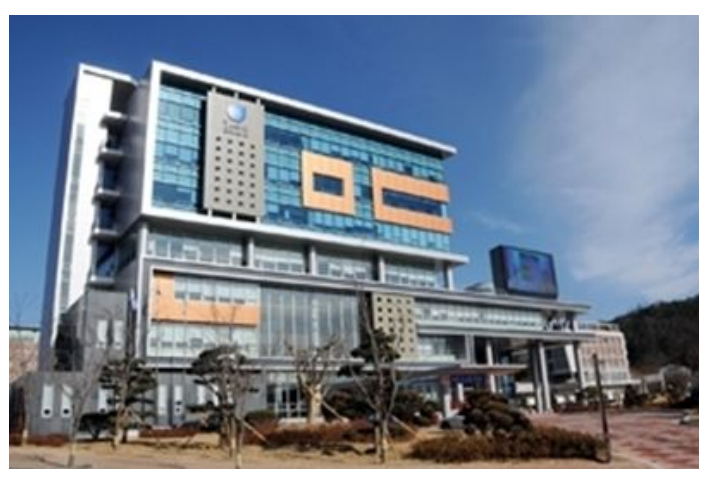

그림 1. 대상건물 전경

\section{$3.2 \mathrm{PV}$ 시스템 개요}

$\mathrm{PV}$ 모듈 수량은 14 직렬 $\times 14$ 병렬로 총 196장이 설치되었으며, 시스템 총 설치용량 은 $41.16 \mathrm{kWp}$ 가 설치되었다. 표 2는 설치된 $\mathrm{PV}$ 모듈의 규격을 나타낸다.

표 2. PV 모듈 규격

\begin{tabular}{c|c}
\hline 구분 & 내용 \\
\hline 모델명 & SMT210-S6 \\
\hline 정격용량 $(\mathrm{Pm})$ & $210 \mathrm{~W}$ \\
\hline 정격전류 $(\mathrm{IPm})$ & $7.91 \mathrm{~A}$ \\
\hline 정격전압 $(\mathrm{VPm})$ & $26.55 \mathrm{~V}$ \\
\hline 단락전류 $(\mathrm{Isc})$ & $8.69 \mathrm{~A}$ \\
\hline 개방전압 $(\mathrm{Voc})$ & $34.15 \mathrm{~A}$ \\
\hline 외형 $(\mathrm{W} \times \mathrm{D} \times \mathrm{H})$ & $1,459 \times 979 \times 40 \mathrm{~mm}$ \\
\hline 무게 & $17.2 \mathrm{Kg}$ \\
\hline 경사각 & $15^{\circ}$ \\
\hline 방위각 & 남서 $15^{\circ}$ \\
\hline Tolerance & $\pm 3 \%$ \\
\hline \multicolumn{2}{|c}{}
\end{tabular}

\section{$3.3 \mathrm{PV}$ 시스템의 발전량 분석}

현재 설치된 PV 시스템의 발전효율을 파악 하기 위하여 특정일(2011년 5월 18일)의 일일 발전량을 분석해 보았으며 그 결과는 그림 2 와 같다. 최대 발전량은 일사량이 가장 많은 11 시와 12 시에 $25 \mathrm{kWh}$ 로 나타났으며, 일 발 전량은 총 $215 \mathrm{kWh}$ 로 나타났다. 또한 17 시 이 후에 발전량이 없는 것은 대상건물 서쪽에 위 치한 산 지형에 의한 것이라 판단되었다. 


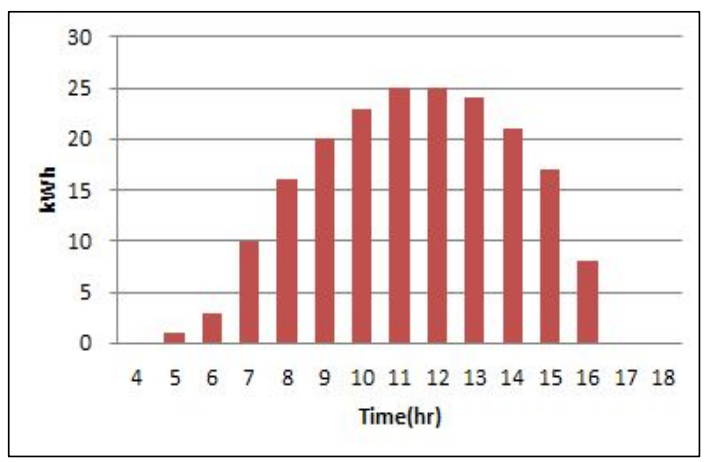

그림 2. 일일 발전량(2011.05.18)

\section{4 법규에 따른 검토1)}

(1) 건축공사비의 $5 \%$ 적용(11.04.13 이전)

대상건물의 설계시점은 2009년이므로 신재 생에너지 설치비용은 총 건축공사비의 $5 \%$ 가 적용되었다. 표 3 은 대상건물의 총 공사비에 대한 대체에너지 설비 투자비용과 그 비율을 나타낸다.

표 3. 총공사비에 대한 투자비율

\begin{tabular}{c|c}
\hline 총공사비 & 6,928 백만원 \\
\hline $\begin{array}{c}\text { 대체에너지 설비 } \\
\text { 투자비용 }\end{array}$ & 351 백만원 \\
\hline $\begin{array}{c}\text { 건축공사비에 대한 } \\
\text { 대체에너지설비 투자비율 }\end{array}$ & $5.07 \%$ \\
\hline
\end{tabular}

신재생에너지 설비 설치용량은 다음 식을 통 하여 산정할 수 있다.

신재생에너지설비 설치용량 $=\frac{\text { 신재생에너지 투자비용 }}{\text { 설치 단가 }}$

대상건물의 설계시점인 2009년 신재생에너 지 원별 상한설치단가는 표 4 와 같다.

대상건물은 일반건물에 속하며 고정식 태 양광 설비가 설치되어 있으므로 설치단가 $9,240 / \mathrm{kW}$ 를 적용하였다. 그 결과 계산된 설

1) 지식경제부, 공공기관 신축건물에 대한 신재생에너지 설치의무화사업 안내.
치용량은 최소 $37.80 \mathrm{~kW}$ 이며, 실제 설치용량 은 그보다 많은 $41.16 \mathrm{~kW}$ 를 설치하였다.

표 4. '09년 신 재생에너지 원별 상한설치 단가

\begin{tabular}{|c|c|c|c|}
\hline \multicolumn{3}{|c|}{ 구분 } & 설치단가 \\
\hline \multirow{4}{*}{$\begin{array}{l}\text { 태 } \\
\text { 양 } \\
\text { 광 }\end{array}$} & \multirow{3}{*}{ 일반건물 } & 고정식 & $9,240 / \mathrm{kW}$ \\
\hline & & 추적식 & $10,900 / \mathrm{kW}$ \\
\hline & & BIPV & $14,960 / \mathrm{kW}$ \\
\hline & 태양광주택 & 고정식 & $7,210 / \mathrm{kW}$ \\
\hline
\end{tabular}

단위 : 천원, VAT포함

대상건물은 일반건물에 속하며 고정식 태 양광 설비가 설치되어 있으므로 설치단가 $9,240 / \mathrm{kW}$ 를 적용하였다. 그 결과 계산된 설 치용량은 최소 $37.80 \mathrm{~kW}$ 이며, 실제 설치용량 은 그보다 많은 $41.16 \mathrm{~kW}$ 를 설치하였다.

(2) 에너지사용량의 $10 \%$ 공급(11.04.13 이후)

대상건물에 대하여 개정된 규정인 예상에 너지 사용량의 $10 \%$ 이상을 신재생에너지로 공급토록 의무화하는 제도를 만족하는지 검 토해 보았다.

개정된 기준에서 신재생에너지 공급의무 비율 $(\%)$ 은 다음 식으로 산정하고 있다.

$$
\begin{aligned}
& \text { 신재생에너지 공급의무 비율 }=\frac{\text { 신재생에너지 생산량 }}{\text { 예상에너지사용량 }} \\
& \times 100
\end{aligned}
$$

여기서, 신재생에너지 공급의무 비율이란 건축물에서 연간 사용이 예측되는 총 에너지 량 중 그 일부를 의무적으로 신재생에너지 설 비를 이용하여 생산한 에너지로 공급해야 하 는 비율을 의미한다. 또한, 예상 에너지 사용 량이란 건축물에서 연간 사용이 예측되는 총 에너지의 양을 보정한 값을 말한다.

예상에너지 사용량은 다음 식으로 산정한다.

예상 에너지 사용량 $=$ 건축연면적 $\times$ 단위에너지 사용량 $\times$ 용도별 보정계수 $\times$ 지역계수 
건축용도별 보정계수는 에너지 관리 공단 에서 표 5 와 같이 제공하고 있으며, 지역계수 는 경북의 경우 0.98 을 적용한다.

표 5. 건축물 용도별 보정계수

\begin{tabular}{l|c|c|c}
\hline \multicolumn{2}{c|}{ 구분 } & $\begin{array}{c}\text { 단위 } \\
\text { 에너지사용량 } \\
\left(\mathrm{kWh} / \mathrm{m}^{2} \cdot \mathrm{yr}\right)\end{array}$ & $\begin{array}{c}\text { 용도별 } \\
\text { 보정계수 }\end{array}$ \\
\hline \multirow{4}{*}{ 공공용 } & $\begin{array}{c}\text { 교정 및 } \\
\text { 군사시설 }\end{array}$ & 392.07 & 1.64 \\
\cline { 2 - 4 } & 방송통신시설 & 490.18 & 1.31 \\
\cline { 2 - 4 } & 업무시설 & 371.66 & 1.73 \\
\hline
\end{tabular}

따라서 건물의 예상 에너지사용량은 식 (3) 에 의해 4,146,139kWh/yr 임을 알 수 있다.

신재생에너지 생산량은 식(4)로 산정할 수 있으며, 신재생에너지원에 따른 단위 에너지 생산량 및 원별 보정계수는 태양광의 경우 표 6 과 같다.

신재생에너지 생산량 $=$ 원별 설치규모 $\times$ 단위에너지 생산량 $\times$ 원별 보정계수

표 6. 단위에너지 생산량 및 보정계수

\begin{tabular}{c|c|c|c|c}
\hline \multicolumn{2}{c|}{ 신재생에너지원 } & \multicolumn{2}{|c|}{$\begin{array}{c}\text { 단위에너지 } \\
\text { 생산량 }\end{array}$} & $\begin{array}{c}\text { 원 별 } \\
\text { 보정계수 }\end{array}$ \\
\hline \multirow{2}{*}{ 태양광 } & 고정식 & 1,358 & $\mathrm{kWh} /$ & 6.17 \\
\cline { 2 - 3 } & 추적식 & 1,765 & $\mathrm{kWyr}$ & 5.35 \\
\hline
\end{tabular}

식 (4)에 의하여 신재생에너지 생산량은 $344,873.9$ $\mathrm{kWh} / \mathrm{yr}$ 로 계산되었다. 이렇게 계산된 예상에 너지 사용량과 신재생에너지 생산량을 가지 고 최종적으로 신재생에너지 공급의무비율을 식 (2)를 통하여 구할 수 있다. 원별 설치 규 모를 현재의 $41.16 \mathrm{kWh}$ 를 적용하여 계산된 신재생에너지 의무 공급비율은 연간 약 $8.3 \%$ 로서 기준인 $10 \%$ 를 충족시키지 못하는 것으 로 나타났다.

\section{4. 신재생에너지 공급비율 분석}

\section{1 시뮬레이션 조건}

대상건물의 모델링은 GooGle SketchUp의 OpenStudio를 활용하여 건물의 Geometry를 작성하였으며, 이후 Energy Plus로 연계하여 세부사항을 입력하였다.

건물의 조닝은 건축도면을 바탕으로 실별 구분을 하였으며, 총 65 개의 존으로 구성되었 다. 건물의 Geometry를 작성한 후, 도면을 통 하여 외벽, 창호, 내벽, 바닥, 지붕, 천정 등의 자재 정보를 수집하였고, 'Material' Class에 이들의 물성치를 적용하였다.

대상건물은 냉난방을 시스템 에어컨에 의 하여 실시하고 있으나, 본 시뮬레이션에서는 'HVACTemplate:Zone:IdealLoadAirSystem' 을 적용하였다. 이는 실내의 부하에 따라 이 상적인 시스템에 의해 공조가 이루어진다고 가정하는 것이다.

재실자, 조명, 기기의 스케쥴은 일반적인 업무용 건물의 스케쥴을 사용하였으며, 그 내 용은 그림 3 과 같다. ${ }^{2)}$

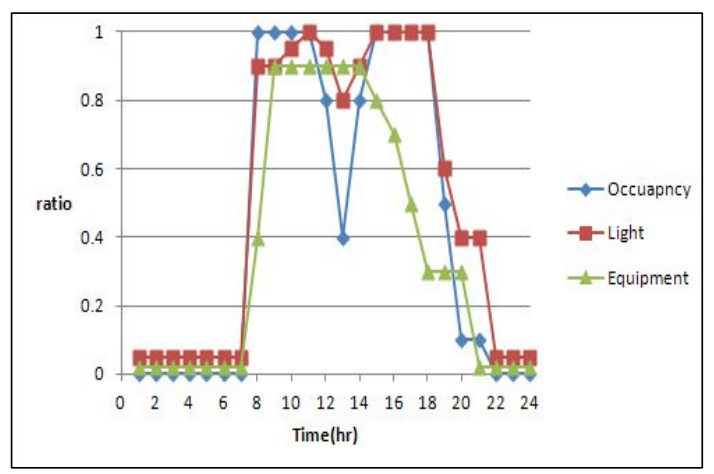

그림 3. 스케 쥴

기상데이터의 경우 대상건물이 위치한 지 역의 데이터를 사용하는 것이 가장 바람직하

2) Office Occupancy, Schedule for Occupancy, User's Manual for ANSI/ASHRAE/IESNA Standard 90.1-2004

한국태양에너지학회 논문집 Vol. 32, No. 2, 2012 
나, 구미지역의 기상데이터 정보가 부족하여 인접지역인 대구지역의 기상데이터를 사용하 였다.

\section{2 신뢰도 분석}

$\mathrm{PV}$ 시스템의 건물 에너지 공급비율을 분 석하기에 앞서, 시뮬레이션 결과값에 대한 $\mathrm{PV}$ 발전량의 신뢰도를 검토해 보았다. 신뢰 도 분석 방법은 실제 데이터와 시뮬레이션 결 과가 얼마나 오차를 가지는지 정량적으로 평 가할 수 있는 방법으로 $\mathrm{MBE}$ (Mean Bias Error)라는 통계적 방법을 사용하였으며, 계 산식은 다음과 같다.

$\operatorname{MBE}(\%)=\frac{\sum_{\text {Period }}(S-M)_{\text {interval }}}{\sum_{\text {Period }} M_{\text {interval }}} \times 100$

여기서,

$\mathrm{M}$ : 측정 데이터

$\mathrm{S}$ : 시뮬레이션 결과

이때, 계산된 값이 작을수록 시뮬레이션 신 뢰도는 높다고 할 수 있으며, 일반적으로 그 기준을 $\pm 10 \%$ 이내로 정하고 있다.

표 7은 실제 $\mathrm{PV}$ 시스템 발전량과 시뮬레이 션 결과값을 비교한 것이다. 실제 발전량은 $\mathrm{PV}$ 시스템이 사용되기 시작한 2011년 2월부 터 8월까지의 데이터이며, 시뮬레이션 또한 같은 기간 동안 수행하였다. $\mathrm{MBE}$ 값은 약 $9.4 \%$ 로 시뮬레이션의 결과 값이 신뢰도를 갖 는다고 판단할 수 있다.

표 7. PV 시스템 발전량 비교

\begin{tabular}{c|c|c|c|c|c}
\hline 월 & $\begin{array}{c}\text { 측정값 } \\
(\mathrm{kWh})\end{array}$ & $\begin{array}{c}\text { 시뮬레이션 } \\
(\mathrm{kWh})\end{array}$ & 월 & $\begin{array}{c}\text { 측정값 } \\
(\mathrm{kWh})\end{array}$ & $\begin{array}{c}\text { 시뮬레이션 } \\
(\mathrm{kWh})\end{array}$ \\
\hline 2 & 3,261 & 3,658 & 6 & 4,291 & 4,302 \\
\hline 3 & 5,260 & 4,408 & 7 & 3,461 & 3,998 \\
\hline 4 & 4,469 & 5,102 & 8 & 3,159 & 4,008 \\
\hline 5 & 4,124 & 5,201 & 9 & - & - \\
\hline
\end{tabular}

\section{$4.3 \mathrm{PV}$ 시스템의 건물에너지 공급비율 분석}

신뢰도분석에서 확인된 신뢰도를 바탕으로 현재 설치된 $\mathrm{PV}$ 시스템이 건물에서 소비되 는 전력을 어느 정도 분담하는지 시뮬레이션 을 통하여 분석하였다. 표 8은 시뮬레이션을 통한 월별 건물의 사용전력량과 $\mathrm{PV}$ 발전량 및 신재생에너지 공급비율을 나타낸 것이다.

표 8. 월별 전력소비량 및 $\mathrm{PV}$ 발전량

\begin{tabular}{c|c|c|c|c|c|c|c}
\hline 월 & $\begin{array}{c}\text { 건물소비 } \\
\text { 전력 } \\
(\mathrm{kWh})\end{array}$ & $\begin{array}{c}\mathrm{PV} \\
\text { 발전량 } \\
(\mathrm{kWh})\end{array}$ & $\begin{array}{c}\text { 신재생에 } \\
\text { 너지공급 } \\
\text { 비율 } \\
(\%)\end{array}$ & 월 & $\begin{array}{c}\text { 건물소비 } \\
\text { 전력 } \\
(\mathrm{kWh})\end{array}$ & $\begin{array}{c}\mathrm{PV} \\
\text { 발전량 } \\
(\mathrm{kWh})\end{array}$ & $\begin{array}{c}\text { 신재생에 } \\
\text { 너지공급 } \\
\text { 비율 } \\
(\%)\end{array}$ \\
\hline 1 & 45,299 & 2,910 & 6.4 & 7 & 44,382 & 3,998 & 9.0 \\
\hline 2 & 41,028 & 3,658 & 8.9 & 8 & 47,527 & 4,051 & 8.5 \\
\hline 3 & 47,527 & 4,408 & 9.3 & 9 & 43,701 & 3,690 & 8.4 \\
\hline 4 & 43,701 & 5,181 & 11.9 & 10 & 45,299 & 4,104 & 9.1 \\
\hline 5 & 46,413 & 5,248 & 11.3 & 11 & 44,421 & 2,980 & 6.7 \\
\hline 6 & 45,732 & 4,302 & 9.4 & 12 & 43,701 & 2,815 & 6.4 \\
\hline
\end{tabular}

시뮬레이션 분석 결과 $\mathrm{PV}$ 시스템의 건물 에너지 공급비율은 월별 $6.4 \% \sim 11.9 \%$ 의 분 포를 나타내었으며, 연간 평균 $8.8 \%$ 로 나타 났다. 이는 현재 에너지 사용량의 $10 \%$ 를 신 재생 에너지로 공급해야하는 의무사항에 미 치지 못하는 것을 알 수 있다. 이러한 현재 상 황과 관련하여 법률개정 이전의 건물들이 현 행 법규에 맞출 필요는 없으나 에너지의 중요 성이 널리 확대되고, 신재생에너지 법규가 날 로 강화되는 상황에서 기존 건물들 또한 기존 에 설치된 신재생 설비를 이용하여 신재생에 너지 공급비율을 향상시킬 필요가 있다고 판 단되었다. 이에 따라 기존 설비 시스템을 이 용한 신재생에너지 공급비율을 높일 수 있는 방안에 대하여 살펴보았다.

\section{4 신재생에너지 공급비율 향상 방안}

기존의 시스템을 이용하여 신재생에너지 공급비율을 향상시킬 수 있는 방법에는 크게 다음과 같은 방법이 있을 수 있다. 
- 기존 신재생 설비 시스템을 이용한 방법

- 추가적 신재생에너지 증설

- 건물에너지 저감을 통한 공급비율 향상 이러한 방법 중 본 연구에서는 기존의 신재 생 설비 시스템을 이용하여 에너지 공급비율 을 향상시키는 방안에 대하여 살펴보았다.

기존 $\mathrm{PV}$ 시스템을 이용하여 신재생에너지 공급비율을 향상시키는 방법에는 아래의 다 섯 가지 경우가 있을 수 있다.

- 태양광 모듈의 증설

- 효율이 좋은 모듈로 교체

- 추적식 태양광 어레이 설치

- $\mathrm{PV}$ 모듈의 온도제어

- 태양광 어레이 각도 조절

이중 태양광 어레이의 각도 조절은 발전성 능에 크게 영향을 미치며, 추가적인 비용 없 이 신재생에너지의 공급비율을 향상시킬 수 있는 방법이라고 할 수 있다. 따라서 본 연구 에서는 태양광 어레이 각도를 다음 $\mathrm{CASE}$ 와 같 이 변경시키며 발전량 변화를 예상해 보았다.

표 9. CASE

\begin{tabular}{c|c}
\hline CASE 1 & 기존 PV 어레이 각도 \\
\hline CASE 2 & 지역별 최적각도 적용 \\
\hline CASE 3 & 계절별 최적각도 적용 \\
\hline CASE 4 & 월별 최적각도 적용 \\
\hline
\end{tabular}

$\mathrm{CASE} 1$ 은 기존 $\mathrm{PV}$ 어레이 각도인 $15^{\circ}$ 를 적용하였다. CASE 2, CASE 3은 각각 지역 및 계절별 $\mathrm{PV}$ 어레이의 최적설치 각도로서 기존 문헌에서 경북지역은 연평균 $32^{\circ}$, 계절 별로는 봄(3 5월) $19^{\circ}$, 여름(6 8월) $2^{\circ}$, 가을 (9 11월) $44^{\circ}$, 겨울(12 2월) $57^{\circ}$ 로 제시하고 있으며, 이 값을 적용하였다.3) CASE 4의 월 별 최적각도는 시뮬레이션에서 최대 발전량 을 나타내는 각도를 선정하여 표 10 과 같이 적용하였다.

3) 유권종 외, '전문가시스템을 이용한 태양광 어레이의 최적설치 각도에 관한 연구', 태양에너지학회 논문집, 2007
표 10. 월별 어레이 최적각도

\begin{tabular}{c|c|c|c}
\hline 월 & 최 적 각 도 & 월 & 최 적 각 도 \\
\hline 1 & $54^{\circ}$ & 7 & $18^{\circ}$ \\
\hline 2 & $50^{\circ}$ & 8 & $22^{\circ}$ \\
\hline 3 & $39^{\circ}$ & 9 & $32^{\circ}$ \\
\hline 4 & $25^{\circ}$ & 10 & $47^{\circ}$ \\
\hline 5 & $18^{\circ}$ & 11 & $53^{\circ}$ \\
\hline 6 & $16^{\circ}$ & 12 & $55^{\circ}$ \\
\hline
\end{tabular}

\section{5 시뮬레이션 결과 분석}

그림 4는 각 CASE 별 연간 발전량을 비교 한 것이며, $\mathrm{PV}$ 발전량에 따른 신재생에너지 공급비율을 표 11에 나타내었다.

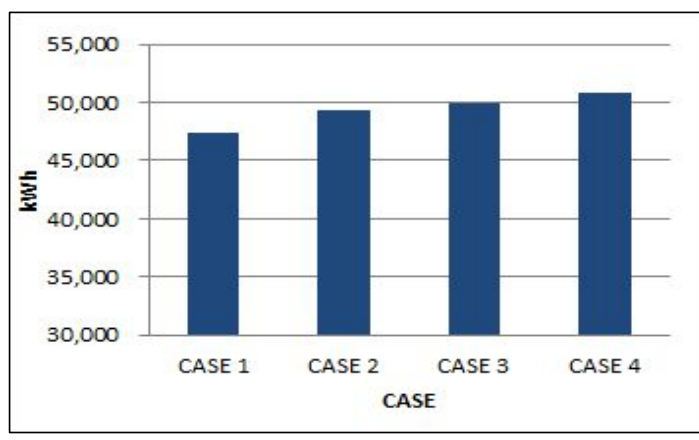

그림 4 CASE별 연간 발전량 비교

표 11. PV 발전량에 따른 신재생에너지 공급비율

\begin{tabular}{|c|c|c|c|c|}
\hline & $\begin{array}{c}\text { 건물소비전력 } \\
(\mathrm{kWh} / \mathrm{yr})\end{array}$ & $\begin{array}{l}\mathrm{PV} \text { 발전량 } \\
(\mathrm{kWh} / \mathrm{yr})\end{array}$ & $\begin{array}{c}\text { CASE 1 } \\
\text { 에 대한 } \\
\text { 증가량 } \\
(\mathrm{kWh} / \mathrm{yr})\end{array}$ & $\begin{array}{c}\text { 신재생에너지 } \\
\text { 공급비율 } \\
(\%)\end{array}$ \\
\hline CASE 1 & \multirow{4}{*}{538,730} & 47,345 & - & 8.8 \\
\hline CASE 2 & & 49,406 & 2,061 & 9.2 \\
\hline CASE 3 & & 49,889 & 2,544 & 9.3 \\
\hline CASE 4 & & 50,904 & 3,559 & 9.4 \\
\hline
\end{tabular}

현재 대상건물과 같은 조건의 $\mathrm{CASE} 1$ 의 경우, 연간 $47,345 \mathrm{kWh}$ 의 발전량을 나타내었 다. 지역별 최적값인 $32^{\circ}$ 를 적용한 CASE 2의 경우는 CASE 1 보다 $2,061 \mathrm{kWh}$, 약 $4.4 \%$ 가 증가한 $49,406 \mathrm{kWh}$ 를 나타내었다. 계절별 최 적값과 월별 최적값을 적용한 $\mathrm{CASE} 3$ 과 $\mathrm{CASE} 4$ 의 경우도 CASE 1 과 비교하여 각각 $2,544 \mathrm{kWh}, 3,559 \mathrm{kWh}$ 만큼의 발전량 증가를 
나타내었으며, 약 $5.4 \%, 7.5 \%$ 가 증가한 $49,889 \mathrm{kWh}$, $50,904 \mathrm{kWh}$ 의 연간 발전량을 나타내었다. 이 상의 결과를 바탕으로 기존의 $\mathrm{PV}$ 시스템을 이용 한 각도 조절만으로도 연간 최대 약 $3,600 \mathrm{kWh}$ 의 전력을 더 생산할 수 있다는 것을 알 수 있다.

표 11에서 알 수 있듯이 태양광 어레이의 각도 조절을 통한 전력 생산량이 증가함에 따 라 건물의 신재생에너지 공급비율을 증가시 킬 수 있으나 기존에 설치된 태양광 어레이의 각도를 조절하여 신재생에너지 공급비율을 높 이는 데에는 한계점이 있다고 판단된다.

\section{5. 결 론}

본 논문은 신재생에너지의 사용의 확대와 이 에 따른 법적규제가 강화됨에 따라 기존의 신 재생에너지시스템 중 태양광 발전시스템이 설 치된 건물을 대상으로 사용현황을 분석한 후, 기존의 시스템을 활용하여 추가적인 비용 없이 신재생에너지 공급비율을 향상시키는 방안을 모색해 보았다. 본 연구의 결과는 다음과 같다.

(1) 기존 건축공사비의 $5 \%$ 가 신재생에너지 설 비에 투자된 건물을 대상으로 예상에너지 사용량의 $10 \%$ 를 신재생에너지로 공급하여 야 한다는 개정된 기준을 적용하여 보았다. 대상건물은 PV 시스템이 설치되어 있으며, 분석결과 $8.8 \%$ 의 공급비율을 나타내어 기 준을 만족시키지 못하는 것으로 나타났다.

(2) 기존의 PV 시스템을 이용하여 추가적인 비 용 없이 신재생에너지 공급비율을 높이기 위한 방법으로 태양광 어레이의 각도를 조 절하는 방법에 대하여 비교하여 보았다. 월 별 최적각도를 적용한 CASE 4의 경우 기존 $\mathrm{PV}$ 시스템의 발전량보다 약 $3600 \mathrm{kWh}$ 의 전 력을 더 생산할 수 있었으며 CASE 1과 비 교하여 약 $7.5 \%$ 의 증가율을 나타내었다.

(3) $\mathrm{PV}$ 시스템의 발전량이 증가함에 따라 신 재생에너지 공급비율이 CASE 4에서 최 대 $9.4 \%$ 까지 증가하였다.

이상의 결과를 바탕으로 기존의 PV 시스템
을 이용하여 추가적인 비용 없이 태양광 어레 이에 최적각도를 적용함으로써 건물에서 신재 생에너지 공급비율을 향상시킬 수 있다는 것을 알 수 있었다. 그러나 이러한 방법은 한계가 있 음을 알 수 있으며, 이러한 방법에 더하여 건물 에너지 절약을 통한 노력이 더해진다면 신재생 에너지의 공급비율을 향상시키고 에너지 절약 을 할 수 있는 방안이 될 수 있을 것이다.

향후 PV 어레이가 최적각도를 추적할 수 있는 알고리즘에 대한 연구가 필요할 것으로 판단된다.

\section{후 기}

이 논문은 2011년도 정부(교육과학기술부) 의 재원으로 한국연구재단의 지원을 받아 수 행된 기초연구사업(20110012071)임.

\section{참 고 문 헌}

1. 유권종 외, 전문가시스템을 이용한 태양광 어레이의 최적설치 각도에 관한 연구, 태 양에너지학회 논문집, V.27, N.3, 2007.

2. 오명석 외, 아파트에 적용된 태양광발전시 스템의 성능평가 및 개선방안에 관한 연구, 대한건축학회 논문집, 제 24권 제 10호, 2008.

3. 송종화 외, 건물일체형 투광성 $\mathrm{PV}$ 모듈의 설치각도별 발전특성에 관한 연구, 한국태 양에너지학회 논문집, V.28, N.02, 2008.

4. 조덕기 외, 국내 태양광시스템 설치를 위한 수평면 전일사량과 일조시간 정밀조사, 태 양에너지학회논문집, V.31, N.3, 2011.

5. 에너지관리공단, 공공기관 신축 건축물에 대한 신재생에너지 설치 의무화사업.

6. Office Occupancy, Schedule for Occupancy, User's Manual for ANSI / ASHRAE / IE SNA Standard 90.1-2004.

7. 신에너지 및 재생에너지 개발·이용·보급촉 진법 제 15 조.

8. 지식경제부, 공공기관 신축건물에 대한 신 재생에너지 설치의무화사업 안내. 